\title{
Coordinated Development of Community Rights and Land Rights: Realization and Development of Farmland Expropriation Intergenerational Equity
}

\author{
Changjian Li, Yaqun Wang \\ Huazhong Agriculture University, Wuhan, Hubei, 430070
}

\begin{abstract}
Land is an important resource shared and shared by present and future generations, and the intergenerational fairness of land interests is difficult to realize is also an important issue facing society. The new urbanization process is accelerating, the agricultural land expropriation is also in full swing, the process involves both the contemporary land rights and interests are damaged, not longterm protection of the plight of land rights and interests of future generations involved in the issue of overdraft. This paper attempts to analyze the theory of community development rights and land development rights as the space-time carriers and objects of common realization of intergenerational interests in agricultural land expropriation respectively, from the perspective of community development rights and land development rights, equitable realization of new possibilities.

Keywords: Community development rights; land development rights; agricultural land expropriation; interests to achieve; intergenerational equity
\end{abstract}

\section{Introduction}

Under the precondition of economic, social, political, cultural and ecological civilization, the practice of the right to development in China has a distinct theme and a prominent focus, which is mainly embodied in the economy, society and culture. The right to development has become an important factor in the solution 
of many problems in our country. It is an important problem that the land rights of the peasants in the agricultural land are not guaranteed, and it is also important to maintain the land rights of the intergenerational peasants in the long run. The academic research system perfects to promote the protection of farmers' rights and interests, because the lack of system to some extent caused by the current land problem can not be fundamentally resolved. At the same time, some scholars focus on the creation of land rights and the perfection of land rights system, trying to strengthen the integrity and mobility of the land rights system to break through the intergenerational equity difficult to achieve. In the right setting and system improvement, especially the right to development research highlights, of which the right to land development research more prominent.

\section{The Theoretical Basis: The Right to Community Development, Land Development Rights and Intergenerational Equity Theory}

\subsection{Community Development Right - the Spatiotemporal Carrier of the Intergenerational Fairness in Agricultural Land Expropriation}

The right to community development has been concerned about the rapid development of market economy, rural grassroots organizations form of management innovation, rural democratic rule of law to accelerate the background of the times, it should be said that the right to exist from the beginning to the development stage to be summoned, Development of the product, it is the inevitable combination of factors and changes in the results.

The right to community development is undoubtedly an integral part of the right to development. Community as an organizational unit, enjoy the political, economic, cultural and other rights, as a collective collection of individuals, but also have the members enjoy the real right to development. Therefore, based on the dual identity of the community itself, the right to community development not only has the collective composition of individual human rights, but also have organizational power. The so-called community development rights, is based on the main development rights and the right to develop the right to achieve the integration of space-time carrier based on the form of community to enjoy the economic and political and cultural development rights of all sides. The creation of community development right pursues the multiple values of justice, harmony and order. The creation of the right of community development has changed the static and plane thinking of the realization of the traditional subjective right and the object right, and formed a dynamic and three-dimensional right construction, which mainly promotes the collective realization of human development in the form of community development. In the background of the new urbanization, the problem of inter-generational fairness of farmland expropriation emerges today. Difficulties and contradictions are difficult to completely divide the level and type. The static way can only solve the problem of unilateral and low-level, the 
dynamic right of community development, the form provides a new possibility for the realization of intergenerational fairness in agricultural land expropriation, which provides a new form for the benefit of the generations and the development of rights and interests.

The right to community development emphasizes the right to development, but differs from the general right to development. In the rapidly changing economy, changing social environment, community development should be the pursuit of internal and external development of the common realization. The internal development requires the community to realize the rights of the community members in the dual aspects of the right to subsistence and the right to development, and to seek to maximize the existing and future members' interests in the community, "he said." The development of the community needs to be improved and developed in the political, economic and cultural rights. Furthermore, considering the factors of community members' intergenerational development and the sustainable development of community organizations, community development rights should also pursue the common development in time and space.

\subsection{The right to land development - farmland expropriation fairness in the intergenerational realization of the object}

The background of the right creation reflects the origin of the demand by the right, but the epoch-making significance of the right after the development (righteousness of the theory and contemporary practice) is the value of the right research. Land in any country is an important means of production and wealth, and the full value of the land to play a large extent depends on the rational allocation of land resources and use, depends on a variety of land rights creation and sound. The existing land rights are mostly static land "right of subsistence", which is dependent on the traditional land rights system, and can not completely solve the new problems in the new historical conditions of land expropriation, which put forward new requirements for the creation of land rights

Land development rights are accompanied by economic development, urban population growth, land value appreciation arising, is an "exotic", is a kind of urbanization birth of property. Originally created to protect agricultural land, it was originally called "the right to agricultural land development." The system originated in the United Kingdom and was applied to those who benefited from planning control to collect the money to compensate the landowners whose interests had been compromised. China's legislation does not define land development rights, land rights system does not provide for land development rights. The discussion and practice of the concept of land development right already exist. The study of the concept of land development right is the most research field of land development right. The scholars of law, politics, economics, philosophy and other fields are defined from the angle of disciplinary standpoint. Some scholars believe that the right to land development is "the right to change the land for the use of different nature, is a division with the land ownership and separate disposal of property rights, it can be integrated with land ownership 
Owned by the land ownership of landowners It is also the most important right in the land disposition right. "It has the five characteristics of abstraction, delay, objectivity, future, and real estate, which can be divided into two parts: one is the land ownership, the other is land ownership. Li Changjian and other scholars basically advocated the right to land development is the allocation of land to the landowner, the state tax revenue to adjust. To sum up, the basic connotation of land development right refers to the right to use the land for redevelopment, that is, the right of the land owner or land user to obtain land development income by changing existing land use or raising land use degree. The nature of a "land ownership can be separated from the independent property rights." Can be dominated by the land owners unified, can also be owned by the land development rights only without ownership of land ownership. Its object is not an independent thing, but the land development and utilization of the developmental benefits arising from. It can be concluded that the right to land development was changed primarily to preserve the agricultural properties of agricultural land. Similarly, in some parts of China also carried out some similar to the creation of land development rights trading market practice, research found in the more typical is the land of Chongqing mode.

The right to land development emphasizes existing land rights and future land rights and interests, attention to land stock benefits and incremental benefits, focusing on the sustainable development of land, of course, also affects the contemporary and future generations of land rights and interests. In the land system reform, increasing the right to land development research and application of the land problem is of great significance.

\subsection{The foothold - intergenerational equity theory}

Intergenerational equity discussed in agricultural land expropriation is the intergenerational equity under the concept of sustainable development, and it is also a basic value orientation of the theory of sustainable development. Intergenerational equity is a kind of fairness under the main body, which means the fairness between present and future generations is the longitudinal embodiment of fairness in the time dimension. This argument was first put forward by Peike, he believes that the so-called intergenerational equity problem is the result of the current decision-making or how the consequences of the fair distribution of future generations between the problem, it is mainly related to contemporary people and between generations Welfare and resource allocation. The earliest theory of intergenerational equity was proposed by the American international environmental jurist, Ms. Yisi Brown Weiss, in her 1989 book on Fair Treatment of Future Humanity: International Law, Common Heritage, Generational Equity: "At any given time, each generation is the custodian or trustee of the earth and is the beneficiary of the result of the commission of the offspring, which gives the responsibility for the protection of the earth and the right to use the earth. Intergenerational equity theory assumes that all countries have intergenerational responsibility for future generations. 
From the practical sense, the theory of intergenerational equity is based on the protection of human interests, while emphasizing sustainable and equality, that all resources of society as a whole belong to all human beings, between generations is equal, between generations is also the same Everyone in the contemporary world does not have the right to consume the resources of future generations. Based on this, the author thinks that the intergenerational conflict of land benefit in the agricultural land expropriation is the conflict between the present generation and the descendants in the land resources' enjoyment, use and distribution of interests. Land resources are limited, accompanied by changes in the objective climate and natural conditions, land resources show a decline or decline in the quality of resources, the contemporary people consume more, for future generations to use the quantity and quality is relatively reduced, which The intergenerational fairness of land benefit has appeared.

There is an important concept of "trusteeship" in the intergenerational equity, namely that the resources are the common wealth of the present generation and the descendants and that "the earth is not the property we inherited from the ancestors" but "we borrowed from the children ". Therefore, in the land resources, each generation of mankind is the trustee of future generations, has the obligation to the land resources are intact to future generations. But the problem is that the contemporary is the existing, its rights are clear legal protection, and its interests are also represented, and the corresponding protection of the main body, and future generations is uncertain, to achieve intergenerational equity needs Reflect and consider the interests of future generations? In this regard, the personal analysis of the scholars related to the idea that the realization of the fairness of intergenerational use of reference, including "the interests of future generations to absorb said," "future generations of people that people", "future generations really say" Say".

\section{The agricultural land expropriation in the intergenerational fair realization of the plight of the analysis}

\subsection{The drawbacks of agricultural land highlighting, overdraft future generations of land interests}

The traditional land use and development model is formed in the early stage of industrial society. It is a development mode which is biased toward "anthropocentrism" and "contemporary egoism". In the specific historical development stage, the traditional land use pattern makes land Society, agriculture and so on. It has the historical inevitability of existence, and also makes the human beings form certain fixed thinking and consciousness mode, which has the dependence on the traditional land use pattern. And then the traditional land use and development model is the product of a specific historical period, there are inherent flaws. In the land resources and the pursuit of sustainable development of the limited moment, the traditional model of land use and land rights protection into a "non-sustained vicious development" state. 
In the traditional land use patterns and land value-added benefits to attract, the more serious disadvantages of agricultural land expropriation. According to statistics, Gansu Province, beyond the scope of allocation of land allocated, not approved first, the illegal use of agricultural land, illegally encircle the land of farmers, the transfer of land, collective land illegally transferred for real estate development, illegal establishment of parks and other related land area 1103.9 hectares; Sichuan Province to clean up the new "Land Management Law" since the illegal transfer of land 2514 acres, 6454 acres of unauthorized park cases; Shanxi Province, investigation of all types of rural land law cases 17,800 , of which the allocation of land for real estate the development of 328 cases, involving land area of 1386 acres; Guizhou Province, illegally cleared up 18,900 acres of agricultural land encroachment, the transfer of illegal transfer of 935.89 acres of real estate development and so on. Farmland in a certain stage of the collection of the amount and area to follow the appropriate use, reasonable development, the principle of sustainable development, beyond the planning of agricultural land expropriation, illegal occupation of land is actually consumed in the future value of land, that is, Land rights and interests.

\subsection{The right to development of rural land is not clear, the development of land rights and interests of farmers lack the basis for future generations}

There are many reasons for unclear land development rights in rural areas. In the process of research, scholars mainly focus on two points: the definition of legislation is unclear and the main body of rights is unknown. On the one hand, the current land development rights have not been clearly defined in our country's legislation, and the land development rights of peasants in agricultural land expropriation are lacking. The academic community strongly urges the establishment of such a right and tries to clarify the feasibility and necessity, but it is still difficult to practice because the attribution has not been finalized. On the other hand, according to the existing law, China is the implementation of land public ownership, rural land except for the law expressly provides for the state, are owned by the peasant collective, but what is the "peasant collective"? Neither the "Constitution" nor the "Land Administration Law" is clearly defined, only the use of enumerated ways that the management of rural land management, including village groups, village committees or township (town) rural collective economic organizations. This leads to the loss of the rights and interests of farmers as a land user, and other stakeholders can obtain a large amount of stock and incremental benefits from land expropriation and compensation, which directly damages farmers' land development rights. . Therefore, to protect farmers' land development rights, we must first clear the right to land development. Similarly, in the long-term interests of contemporary people that is the idea of the interests of future generations, to strive for future generations of land development interests, we must clear the contemporary land development rights. 


\subsection{Compensation for agricultural land expropriation is not in place, future generations the right to development of agricultural land can not be compensated}

The Land Administration Law stipulates that "the compensation fee for land acquisition includes land compensation fee, resettlement subsidy and compensation fee for ground attachments and young crops." The land compensation fee is due to the collection of farmers 'collective land to the farmers' collective owners and land the compensation for the losses caused by the users' input and income of land is six to ten times of the average annual output value of the cultivated land in the previous three years. The resettlement subsidy is to resettle the agricultural population whose land is the main means of production and obtain the source of livelihood. Compensation for living and resettlement subsidy According to the agricultural population to be resettled, the resettlement subsidy standard for each agricultural population to be resettled is four to six times of the average annual output value of the cultivated land. However, the sum of the land compensation fee and the resettlement subsidy shall not exceed 30 times of the average annual output value of the three years before the expropriation of the land; the compensation fee for the ground attachments shall be the compensation for the various buildings and structures on the land acquired; Compensation is due to land expropriation is in the growth stage of crops can not be harvested and given land contractor or land user compensation. From the existing provisions can be seen in the compensation for agricultural land in the farmers access to only the land use of agricultural land use benefits compensation, does not include the right to compensation for agricultural land development. Once the agricultural land is expropriated to construction land, is an irreversible process, which means that future generations in the compensation of contemporary agricultural land can not get benefits, there is no preparation for their "reserve share", obviously in the collection of agricultural land Of intergenerational equity can not be achieved.

3.3 The lack of future generations of rights representatives, coupled with the contemporary "can not" + "can not"

Contemporary people are the existence of reality, regardless of capacity and ability to complete and there is a legal sense and a certain sense of the interests of the representative and expression of the main. However, as a human being, the offspring is a kind of virtual conceptual existence. There is no legal representative or agent, and no relevant system protects its rights and interests. Therefore, even if the right is infringed, Rights and interests are damaged, there is no way to express and maintain.

The contemporary people have two problems of "unexpected" and "can not" for the land rights and interests of future generations. On the one hand, it is impossible to think of the future generations, who are the future generations, and the interests of their future generations who can not be sure that contemporary people think that the future existence of future generations should solve their own 
problems, Contemporary people do not exist for the imagination of the person's obligations. On the other hand, it can not do: with the economic development and the environment and land problems, the society has realized the crisis of land resource use and development, most people have realized the importance of land resources and the significance of survival and development. However, the pursuit of "maximizing economic benefits" and "egoistic" thinking, contemporary people think that the existence of human interests and rights are the highest (or most important, first consider) the interests and rights, and future generations of land interests and The right to development is beyond the scope of this generation's vision and consideration.

\section{The right to community development and land development rights synergies: agricultural land acquisition in the realization and development of intergenerational equity}

The realization of intergenerational equity is accompanied by social changes. In today's society, the diversification of the main body, the pluralistic relationship, the pluralistic social interests and the realization of interests can not only rely on the individual's choice and striving, but also need an integrated and multi-factor organization to function. The realization of intergenerational fairness in agricultural land expropriation needs to take the right of community development as the space-time carrier, the realization of land development right as the object, and also the comprehensive synergy of development right. At the same time to achieve intergenerational equity problem must be clear is the first need to ensure that the interests of the people of the long-term development, to achieve quantitative and qualitative growth, to provide a basis for a fair cross, because only the cake bigger, have the possibility of future generations to share. Therefore, to achieve intergenerational fairness in the collection of agricultural land need to be considered, and gradually advance.

\subsection{Strictly limit the area and scope of agricultural land expropriation, and reserve land resources and development rights and interests that future generations deserve}

The positive significance of agricultural land expropriation lies in the rational allocation of land resources, the maximum value of land and the best economic benefits. According to the positive effect analysis, it is beneficial for the contemporary generations to collect reasonably and reasonably farmland. However, the agricultural land expropriation in the state of reality has become the squeezing and irreversible damage to the land value. Therefore, the realization of intergenerational equity based on the present situation analysis must first ensure the existence of intergenerational common interests and Levied in a certain extent and within the limits of the area, for generations to leave there should be the land resources. To this end, on the one hand, the national level needs to strictly enforce the land resources and land assets, macro control and supervision. On the 
other hand, legislation should strictly limit the state's right to collect agricultural land in the "public interest" range, a clear collection shall not be applied to commercial purposes. State-owned land acquired for the purpose of commercial development may only be acquired through contract. The other main business needs construction land can be resolved through two channels: First, make full use of the existing state-owned land; Second, rural collective land can be conditionally enter the construction market.

\subsection{The right to land development, innovation and development of the economic and political role of the community}

The determination of land development right is the foundation of land development right. The current legislation does not clarify the land development rights of farmers, some areas have been piloted according to local conditions, and achieved good results provide a good experience for reference. Such as the legal form of a clear legal rights of property for farmers to implement property rights and interests of farmers, so that farmers have a sense of security and ownership of their own land; the establishment of farmers land property rights trading institutions, the land property rights trading market to get a relatively open and fair, Transparent environment, farmers and land to enter such an environment, the land resources of the market-oriented operation can be achieved, the farmers' own rights and interests have been strictly protected. However, the realization of these goals requires the existence of an implementing agency or organization.

There are many studies on the beneficial exploration of farmers' land development rights protection, but no good measures and countermeasures have been carried out. As mentioned above, the community has basic political and economic functions. With the reform of the market economy and the continuous development of the rural economy, the rural communities should not be neglected in the development of the times and their related functions must be innovated and developed. In the course of clarifying peasants 'land development rights, rural communities, as the middle force between the government and individual farmers, from the perspective of protecting the land development rights of peasants, implement the policy measures for the farmers' land right certification, Attachments and housing, and issued a certificate of title, a clear farmer's land and related property rights. In addition, the current rural economic operation to the market economy and the scale of intensive management changes in rural areas at all levels of the interests of the ongoing differentiation, individual farmers are weak, relying solely on individual farmers or family strength is difficult to prevent market risk, rural communities The economic function of the play at this time is very important. The peasant community acts as a "protection and provision consultation" before and after the peasants carry out the land transaction, and in order to maximize the peasants 'land rights and interests and protect the peasants' land in the orderly operation of the market-oriented mechanism. 


\subsection{A reasonable determination of the value of land development rights, and incorporated into the compensation for agricultural land expropriation}

The compensation fee for land acquisition mainly refers to the economic value of land. Some eastern regions have begun to consider the social security value of land, but the compensation for the value of land development right is not considered. Therefore, it is suggested that the value of land development rights should be taken into account in the process of land expropriation. So, in the collection of agricultural land, how to determine the value of land development rights? First of all, the land has been determined to be levied, it must know that the land converted into land for construction can produce benefits, which can be similar to the block from the similar land converted into the proceeds of construction land to replace, If the land parcels with similar distance to the land are converted into the construction land, the income generated by the professional evaluation institution will be evaluated, and then the value of the land development right will be calculated by the above formula. Then the value of land development rights calculated after the distribution of how to do it? It is recommended that farmers collect $30 \%$ of their income in order to compensate for the value they have accrued over the years due to their labor in the cultivation and maintenance of land. The village collects $40 \%$ of its income for villagers' Labor placement and the establishment of protection funds, and to a certain extent, to protect the basic needs of future generations of farmers, that is, future generations of land development rights and interests of the Government to collect $30 \%$ of its revenue to support the region's infrastructure Construction, and promote the economic development.

\subsection{The right to innovation in community development, to explore the future generations of land development rights agency system}

As the human race has not yet played how to "exercise" their rights? In the collection of agricultural land to achieve intergenerational equity, future generations how to exercise the right to express and enjoy the benefits and development rights? This is a real problem that must be solved in the intergenerational fairness of agricultural land expropriation. As future generations can not rightly state their rights, can not express their wishes and rights, and therefore should be by the contemporary generation of the rights of future generations of agents. Of course, the probability of this consciousness is very low, so the need for a legal coercive force as an agent to protect the rights of agents in the framework of the law under the protection of future generations rights. It is proposed that such a legal representation be delegated to the community, which means that the content of the existing right to community development needs to be innovated. The dual identity of the community makes the right to community development a dual right, both from the outside development of community organizations, but also need to protect the rights of members of the community from within, and community members must also include contemporary community and community descendants. Community agent system in the 
agricultural land fair collection of intergenerational realization mainly for the one hand, the contemporary community as the agent of land rights and interests of future generations, learn from "future generations of groups that" the view, the community as a descendant in the real right Of the legal agent, do so for community management and exercise of power to provide a theoretical basis. On the other hand, in the collection of agricultural land, the community on behalf of future generations to express, accept and manage the right to compensation for agricultural land development.

\section{Conclusion}

The essence of the interest game in the agricultural land expropriation is that the multiple subjects compete for land development gain. In the traditional sense, the pluralistic subject is the existing actual subject and the horizontal subject. Along with the change of the development idea, the right of development and the development of the times demand, the interest subjects in the agricultural land expropriation show the difference of time and space. Nowadays, intergenerational fairness has been widely appeared in the research and practice of environmental protection, natural resources sharing and sharing, and contemporary people are paying attention to and realizing the fairness of intergenerational efforts. As a right to development, many land development rights should be applied to the realization of the inter-generational fairness of agricultural land expropriation, combined with the right of space-time carrier community development in order to achieve the balance of intergenerational interests in farmland expropriation and the effective realization of intergenerational equity.

\section{Acknowledgements}

2015 Ministry of Education of philosophy and social science research major project research project "Study on farmers' land rights and interests in the process of new urbanization" (15SFB2036)

The Ministry of education of philosophy and social science research major project research project "farmers land rights protection research in the process of new urbanization" (14JZD014).

\section{References}

[1] Li Changjian, Wu Wenhui. Study on the Theory of Community Development Rights Based on the Protection of Farmers' Rights [J].Journal of Northwest University of Political Science and Law, 2006, 06: 33-40.

[2] Li Wei. The theory of community development rights of farmers' rights and interests of the legal issues [D]. Huazhong Agricultural University, 2007.

[3] Liu Mingming. The basic theory of land development rights research [D]. Shandong University of Science and Technology, 2007 
[4] Du Zhenghui. Chinese land development rights research [D]. Tongji University, 2007.

[5] Chen Baifeng. Theoretical Basis and Institutional Perspective of Land Development Right [J]. Journal of Law, 2012, 04: 99-114.

[6] Zhao X. Research on compensation standard of agricultural land expropriation - based on sustainable development and fuzzy real options [J]. Journal of Xihua University (Philosophy and Social Sciences), 2012,05: 69-75.

[7] Liu Guozhen, China Land Development Rights [J]. Academic Research, 2005, 10: $64-68+147-148$.

[8] Liu Guozhen. The land development rights in China's land rights system legal status [J]. Academic research, 2007, 04: 84-89.

[9] Liu Lixia. The Game of Power Expansion and Rights Restriction-The Fundamental Crux of Agricultural Land Expropriation and Its Governance [J]. Contemporary Economic Research, 2008, 03: 56-58.

[10] Liu Guozhen. The establishment of land development in China the necessity and feasibility [J]. Hebei Law, 2008,08: 113-116.

[1] Zhang Tingting. Land development rights of land expropriation compensation mechanism research [D]. Lanzhou University, 2014

[12] Li Changjian, Liu Lei. Risk Prevention of Rural Land Transfer Excessive Concentration under Intergenerational Equity [J]. Journal of Shanghai University of Finance and Economics, 2014, 01: 46-53 + 61.

[13] Wang Shu. Intergenerational equity and the rights of future generations subject status [D]. East China University of Political Science and Law, 2007

[14] Li X. Wuhan city land expropriation compensation fairness research [D]. Huazhong University of Science and Technology, 2008

[15] Zhao Xu. Constitution of Compensation Value of Farmland Expropriation and Reconstruction of Subject Relations under the Sustainable Development Perspective [J]. Journal of Nanhua University, 2014, 06: 28-32

[16] Tang Maogang. Land development rights of the value of [J]. Value Engineering, 2015, 05: 26-29.

[17] Xiang Hongbo, Bi Yunlong, Kang Luhao. Analysis of agricultural land expropriation [J]. China Land and Resources Economics, 2015, 10: 70-72.

[18] Liang Ju. Community development based on the legal system of rural land transfer [D]. Huazhong Agricultural University, 2011

[19] Hu Tingting. China's current rural land expropriation compensation system research [D]. Southwest University of Political Science and Law, 2010 